\title{
MYCELIAL BIOMASS CULTIVATION OF Lentinus crinitus
}

\author{
CRESCIMENTO MICELIAL DE Lentinus crinitus
}

\section{Itaruã Machri COLLA ${ }^{1}$; Olavo Bilac Quaresma de OLIVEIRA FILHO' ${ }^{1}$; Janyeli Dorini Silva de FREITAS ${ }^{1}$; Míria Benetati Delgado BERTÉLI' ${ }^{1}$ Giani Andrea LINDE ${ }^{1}$; Juliana Silveira do VALLE ${ }^{1}$; Nelson Barros COLAUTO ${ }^{1}$ \\ 1. Universidade Paranaense, Programa de Pós-graduação em Biotecnologia Aplicada à Agricultura, Umuarama, PR, Brasil. nbc@prof.unipar.br}

\begin{abstract}
Lentinus crinitus is a medicinal basidiomycete, little studied regarding the basic cultivation conditions, which is used in bioremediation and consumed by native Indians from the Brazilian Amazon. Also, it produces a fungal secondary metabolite panepoxydone that has been described as an essential regulator of the inflammatory and immune response. This study aimed to evaluate basic conditions of temperature, $\mathrm{pH}$, and nitrogen concentration and source in the cultivation of $L$. crinitus mycelial biomass. In order to evaluate fungal growth temperature, $2 \%$ malt extract agar (MEA) medium, $\mathrm{pH} 5.5$, was utilized from 19 to $40{ }^{\circ} \mathrm{C}$. For $\mathrm{pH}, \mathrm{MEA}$ had $\mathrm{pH}$ adjusted from 2 to 11 and cultivated at $28{ }^{\circ} \mathrm{C}$. Urea or soybean meal was added to MEA to obtain final concentration from 0.5 and $16 \mathrm{~g} / \mathrm{L}$ of nitrogen, $\mathrm{pH}$ of 5.5 , cultivated at $28^{\circ} \mathrm{C}$. The best temperature growth varies from 31 to $34^{\circ} \mathrm{C}$ and the optimal one is $32.7^{\circ} \mathrm{C}$, and the best $\mathrm{pH}$ ranges from 4.5 to 6.5 and the optimal one is 6.1 . Protein or non-protein nitrogen concentration is inversely proportional to the mycelial biomass growth. Nitrogen concentrations of $2.0 \mathrm{~g} / \mathrm{L}$ soybean meal and urea inhibit mycelial biomass growth in $11 \%$ and $12 \%$, respectively, but high concentrations of $16.0 \mathrm{~g} / \mathrm{L}$ nitrogen inhibit the growth in $46 \%$ and $95 \%$, respectively. The fungus is robust and grows under extreme conditions of temperature and $\mathrm{pH}$, but smaller adaptation with increasing nitrogen concentrations in the cultivation medium, mainly nonprotein nitrogen.
\end{abstract}

KEYWORDS: Axenic cultivation. Cultivation condition. Mycelial biomass growth. Soybean. Urea.

\section{INTRODUCTION}

Lentinus crinitus (L.) Fr. is a wild basidiomycete, native to Brazil, with pantropical (tropical regions of Africa, Asia and America) and neotropical (Central America, southern Florida, Caribbean islands and South America) distribution, frequently found in decomposing tree trunks (SILVA; GIBERTONI, 2006). This fungus grows in several substrates and is utilized in bioremediation (BALLAMINUT; MATHEUS, 2007), product discoloring in the textile industry (SANCHEZLOPEZ et al., 2008; NIEBISCH et al., 2010; ALMEIDA et al., 2018; MARIM et al., 2018) and presents a powerful arsenal of enzymes dedicated to the breakdown and consumption of lignocellulose (VALLE et al., 2014; CAMBRI et al., 2016; CONCEIÇÃO et al., 2017; SANTANA et al., 2018). Moreover, it produces a fungal secondary metabolite panepoxydone that has been described as an inhibitor of NF- $\mathrm{KB}$ activation, and it is a regulator of the inflammatory and immune response (ERKEL; WISSER; ANKE, 2007; WASSER, 2010; CHANG; WASSER, 2012; WASSER, 2017). However, few studies are related to the specific conditions of $L$. crinitus mycelial biomass growth and usually the ones that are utilized are established for other basidiomycetes such as Agaricus brasiliensis (COLAUTO et al., 2008), Lentinula edodes (FENG et al., 2010), Lentinus sajor-caju and Pleutorus spp (ALBUQUERQUE, NOGUEIRA; NASCIMENTO, 2012).

Mycelial biomass production is an alternative to mushroom production due to a better utilization and standardization of the substrate and better contaminant control (EIRA, 2004), mainly for the production of bioactive molecules. L. crinitus is particularly interesting for the mycelial biomass production since this mushroom consumption is little appreciated due to its fibrous texture, despite being consumed by the Sanama (Yanomami) Indians (FIDALGO; PRANCE, 1976; VARGAS-ISLA; ISHIKAWA, 2008). Moreover, this fungus produces panepoxydone, a bioactive fungal metabolite, which can be effectively used against malignant cells, mainly breast cancer (ERKEL; ANKE; STERNER, 1996). Unlike synthetic compounds, fungal metabolites can penetrate into target cell membrane easily, increase its bioefficacy due to the low molecular size, and improve the overall human immune system (SHARMA; ANNEPU, 2018). 
However, for the mycelial biomass production, it is important to determine the optimal cultivation and variation conditions in which the fungus can grow such as the temperature range, initial $\mathrm{pH}$, and nitrogen concentration and source in the cultivation medium (COLAUTO et al., 2008). Temperature is one of the most important factors that affect the mycelial biomass growth among mushroom-producing basidiomycetes. It has such an important role in the fungus adaptation regarding the enzymatic activity that it causes alterations in the metabolism and mycelial biomass growth (MILES; CHANG, 1997). Another important variable that affects the mycelial biomass growth is the $\mathrm{pH}$. Fungi are usually limited to grow in a narrow range of $\mathrm{pH}$, close to neutrality, although some may tolerate extreme $\mathrm{pH}$; this parameter can directly affect the cell membrane and the level of ion dissociation, interfering in the absorption of nutrients and minerals of the environment (DEACON, 2006). The adaptation to different $\mathrm{pHs}$ requires a homeostatistic system of internal $\mathrm{pH}$ and a specific regulatory system which guarantees that the molecules exposed to the environment be secreted only under favorable conditions (PEÑALVA et al., 2008). Another requirement is the nitrogen concentration and source that directly affects the metabolization capacity of the fungus for the mycelial biomass growth and colonization of different types of substrates under different ambient conditions, and ammonium and glutamine sources were the preferred ones (MARZLUF, 1997). In the absence of nitrogen sources, other sources may be utilized, although they are less easily assimilated such as nitrate, urea, uric acid, amines, amides, purines, and pyrimidines (MARZLUF, 1997; WONG; HYNES; DAVIS, 2008). D'Agostini et al. (2011) evaluated the effect of the addition of nonprotein sources and concentrations on the mycelial biomass growth of Pleurotus ostreatus, L. edodes and $A$. brasiliensis and concluded that ammonium sulfate, ammonium:urea sulfate $(1: 1)$, and urea are more appropriate. Das et al. (2015) evaluated Lentinus squarrosulus in submerse cultivation through several nitrogen sources, with greater mycelial biomass growth with yeast extract, a protein nitrogen source, and a smaller growth with ammonium nitrate, a non-protein nitrogen source. Due to the lack of basic and specific parameters for the axenic cultivation of $L$. crinitus, this study aimed to evaluate the temperature, initial $\mathrm{pH}$, and nitrogen concentration and source in the cultivation medium for the mycelial biomass growth of L. crinitus in order to develop the axenic cultivation of this fungus.

\section{MATERIALS AND METHODS}

\section{Biological material}

L. crinitus U9-1 strain from the culture collection of the Laboratory of Molecular Biology of Paranaense University was previously identified by sequencing the internal transcribed spacers (ITS) of ribosomal DNA (MARIM et al., 2018) and deposited in the GenBank database (http://www.ncbi.nlm.nih.gov/genbank/), accession number MG211674. The cryopreserved fungus (MANTOVANI et al., 2012) was recovered on malt extract $\left(20 \mathrm{~g} / \mathrm{L}\right.$; Himedia $\left.{ }^{\circledR}\right)$ and agar $(5 \mathrm{~g} / \mathrm{L}$; Himedia ${ }^{\circledR}$ ), previously autoclaved at $121{ }^{\circ} \mathrm{C}$ for 20 min (TANAKA et al., 2019). The fungus was kept at $25 \pm 1{ }^{\circ} \mathrm{C}$, in the dark for seven days. The inoculum was selected from the mycelial growth edge with uniform appearance and without sectioning.

In addition, incorrect names, synonyms, and eventual typing mistakes or misspellings can lead to confusion and, therefore, the current name should be clear. L. crinitus (current name) has 25 synonyms such as Agaricus crinitus L., Agaricus essequeboensis G. Mey., Lentinus chaetoloma Fr., Lentinus crinitus var. crinitus (L.) Fr., Lentinus crinitus var. denudatus Pilát, Lentinus crinitus var. squamulosus Pilát, Lentinus crinitus var. subcervinus (Berk. \& M. A. Curtis) Pilát, Lentinus crinitus var. subcrinitus Pilát, Lentinus crinitus var. subvillosus Pilát, Lentinus crinitus var. typicus Pilát, Lentinus essequeboensis (G. Mey.) Fr., Lentinus microloma Pat. \& R. Heim, Lentinus rigidulus Berk. \& M. A. Curtis, Lentinus subcervinus Berk. \& M. A. Curtis, Lentinus wrightii Berk. \& M. A. Curtis, Panus crinitus (L.) Singer, Panus crinitus var. crinitus (L.) Singer, Panus wrightii Berk. \& M. A. Curtis, Pocillaria chaetoloma (Fr.) Kuntze, Pocillaria crinita (L.) Kuntze, Pocillaria essequeboensis (G. Mey.) Kuntze, Pocillaria rigidula (Berk. \& M. A. Curtis) Kuntze, Pocillaria subcervina (Berk. \& M. A. Curtis) Kuntze, Pocillaria wrightii (Berk. \& M. A. Curtis) Kuntze, and Polyporus phyllostipes D. Krüger (KIRK, 2019).

\section{Mycelial biomass growth under different cultivation conditions \\ In order to evaluate the effect of} temperature, the fungus was grown in $2 \%$ malt extract agar (MEA) $(20 \mathrm{~g} / \mathrm{L}$ malt extract and $10 \mathrm{~g} / \mathrm{L}$ agar; Himedia ${ }^{\circledR}$ ), with initial $\mathrm{pH}$ of 5.5 , and cultivated from 19 to $40{ }^{\circ} \mathrm{C}$, with variation every 3 ${ }^{\circ} \mathrm{C}$. For the evaluation of the effect of $\mathrm{pH}$, the fungus was grown in MEA at $28{ }^{\circ} \mathrm{C}$ with $\mathrm{pH}$ 
adjusted from 2 to 11 , varying every 0.5 units, adjusted with $\mathrm{HCl}(1 \mathrm{~mol} / \mathrm{L})$ or $\mathrm{NaOH}(1 \mathrm{~mol} / \mathrm{L})$, previously filtered $(\varnothing 0,22 \mu \mathrm{m})$. In order to assess the effect of nitrogen concentration and source, nonprotein nitrogen (urea; $\mathrm{CH}_{4} \mathrm{~N}_{2} \mathrm{O}$ ) or protein nitrogen (soybean meal) was added to MEA to obtain final concentration of $0,5,1,2,4,6,8,10,12,14$, and 16 $\mathrm{g} / \mathrm{L}$ of nitrogen in the cultivation medium, with $\mathrm{pH}$ of 5.5 and cultivation at $28{ }^{\circ} \mathrm{C}$. An MEA disk of 0.5 $\mathrm{mm}$ of diameter, containing mycelia, was inoculated in the middle of the cultivation medium for mycelial grown for 28 days in the dark, and the diameter of the mycelium radial growth was measured from four equidistant points to obtain arithmetic average.
All the treatments were performed randomly and were replicated four times each. The data were evaluated by analysis of variance and the significant differences were determined by Tukey test $(p \leq$ $0.05)$. The ideal values of mycelial biomass growth were determined by regression.

\section{RESULTS}

The fungus was able to grow from 19 to 40 ${ }^{\circ} \mathrm{C}$, but the temperature range that promotes the greatest $(p \leq 0.05)$ mycelial biomass growth was from 31 to $34{ }^{\circ} \mathrm{C}$ (Fig. 1). By polynomial regression $\left(\mathrm{R}^{2}=0.97\right)$, the optimal temperature peak of the mycelial biomass growth was $32.7^{\circ} \mathrm{C}$ (Figure 1).

\section{Statistical analysis}

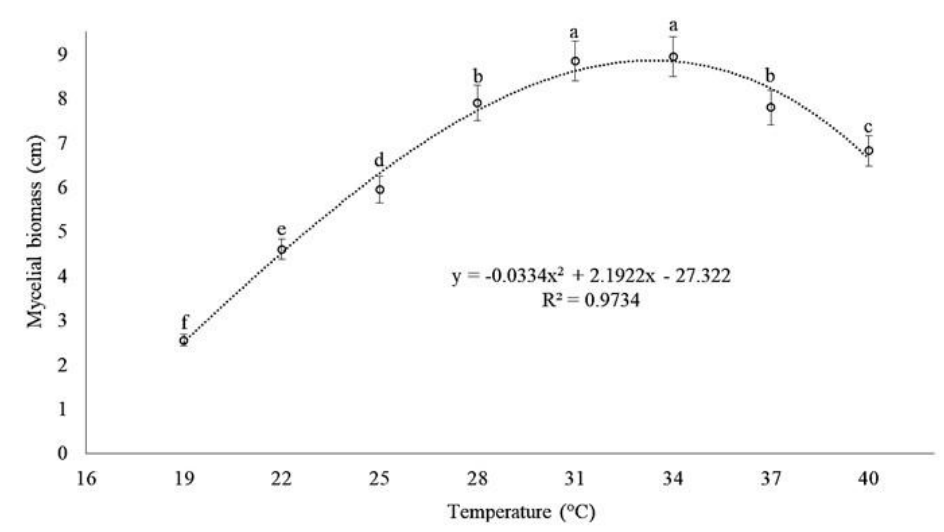

Figure 1. Diameter of Lentinus crinitus mycelial biomass growth in $2 \%$ malt extract agar, initial $\mathrm{pH}$ of 5.5, and cultivated at different temperatures.

Different letters indicate differences $(p \leq 0.05)$ by Tukey test $(\mathrm{n}=4)$.

The fungus was capable of growing in a cultivation medium with the initial $\mathrm{pH}$ from 2.5 to 10.5 , but there was no mycelial biomass growth with $\mathrm{pH}$ from 2 or 11 (Figure 2). The greatest ( $p \leq$
$0.05)$ values of mycelial biomass growth were with $\mathrm{pH}$ from 4.5 and 6.5 and by polynomial regression $\left(\mathrm{R}^{2}=0.95\right)$ the optimal $\mathrm{pH}$ peak for mycelial biomass growth was 6.1 (Fig. 2).

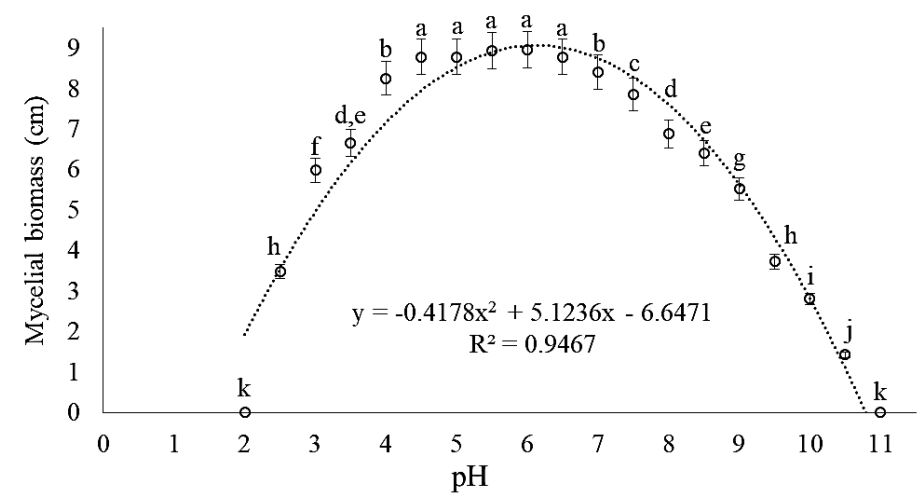

Figure 2. Diameter of Lentinus crinitus mycelial biomass growth in $2 \%$ malt extract agar and cultivated at $28 \pm$ $1{ }^{\circ} \mathrm{C}$ with different values of initial $\mathrm{pH}$ in the cultivation medium.

Different letters indicate differences $(p \leq 0.05)$ by Tukey test $(n=4)$. 
The greatest nitrogen concentration in the cultivation medium inhibited $(p \leq 0.05)$ the mycelial biomass growth, regardless of the nitrogen source (Figure 3). The addition of $2.0 \mathrm{~g} / \mathrm{L}$ of non-protein source inhibited the mycelial biomass growth in $11.9 \%$, while the addition of $16.0 \mathrm{~g} / \mathrm{L}$ inhibited in $95.1 \%$ (Fig. 3), indicating a low metabolization capacity of urea. The addition of protein nitrogen also inhibited the mycelial biomass growth, but in a less intensive manner (Fig. 3). The addition of 2.0 $\mathrm{g} / \mathrm{L}$ of protein nitrogen inhibited the mycelial biomass growth in $11.3 \%$, while the addition of 16.0 $\mathrm{g} / \mathrm{L}$ inhibited $45.6 \%$, with a tendency of fungal adaptation without great effects on the mycelial biomass growth (Fig. 3) and indicating that this wild fungus prefers to grow under conditions with lower nitrogen concentration. There were no differences in the visual density of mycelial biomass ramification among the treatments.

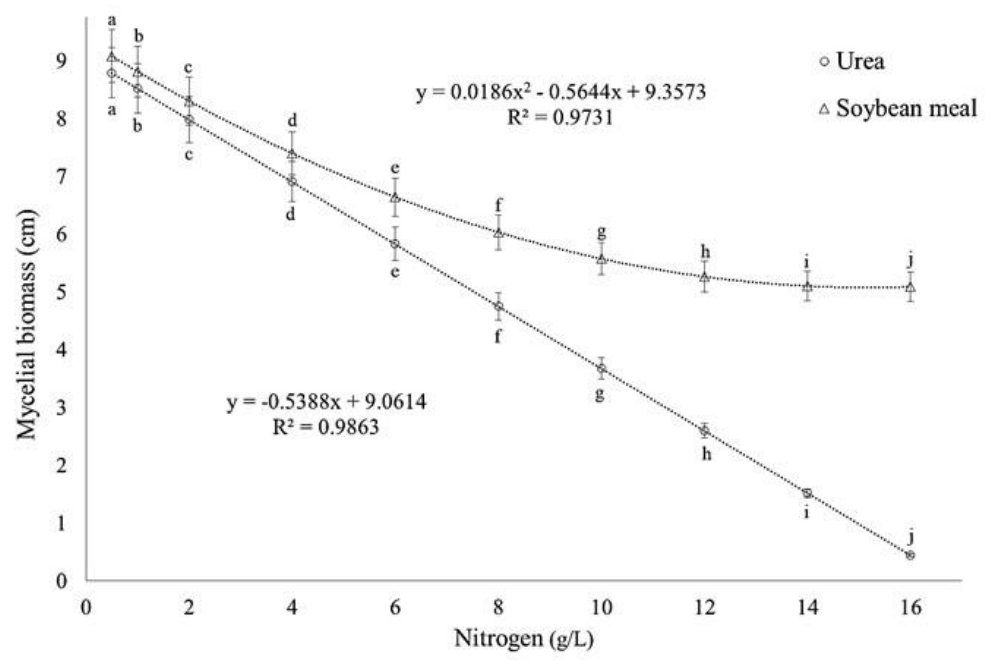

Figure 3. Diameter of Lentinus crinitus mycelial biomass growth in $2 \%$ malt extract agar with addition of protein (soybean meal) and non-protein (urea) nitrogen, initial $\mathrm{pH}$ of 5.5, and cultivated at $28 \pm 1{ }^{\circ} \mathrm{C}$. Different letters in each linear or non-linear equation indicate differences $(p \leq 0.05)$ by Tukey test $(\mathrm{n}=4)$.

\section{DISCUSSION}

The optimal temperature peak for $L$. crinitus mycelial growth reported in our study was $32.7^{\circ} \mathrm{C}$, and it is the first result of ideal temperature for mycelial biomass growth for this basidiomycete. The mycelial biomass grew from 19 to $40{ }^{\circ} \mathrm{C}$, with optimal range from 31 to $34{ }^{\circ} \mathrm{C}$. This ideal temperature range is higher than those reported for other edible commercialized basidiomycetes, which is $28{ }^{\circ} \mathrm{C}$ for $A$. brasiliensis (COLAUTO et al., 2008), $30{ }^{\circ} \mathrm{C}$ for Volvariella volvacea (AKINYELE; ADETUYI, 2005), and $25{ }^{\circ} \mathrm{C}$ for $P$. ostreatus (SALES-CAMPOS et al., 2008) to name a few. However, Vargas-Isla and Ishikawa (2008) reported that the best temperature for mycelial biomass growth was at $35{ }^{\circ} \mathrm{C}$ to Lentinus strigosus, close to the value found in our study with $L$. crinitus. For Chang and Miles (2004), basidiomycetes can be classified into three groups according to the growth temperature: psychrophiles with a minimum temperature below $0{ }^{\circ} \mathrm{C}$, an optimum one around 17 ${ }^{\circ} \mathrm{C}$, and lack of growth above $20^{\circ} \mathrm{C}$; mesophiles with minimum temperature above $0{ }^{\circ} \mathrm{C}$, maximum one below $50^{\circ} \mathrm{C}$, and optimum temperature between
15 and $40{ }^{\circ} \mathrm{C}$; thermophiles with minimum temperature above $20{ }^{\circ} \mathrm{C}$, maximum one at or greater than $50^{\circ} \mathrm{C}$, and optimum temperature around $35{ }^{\circ} \mathrm{C}$ or higher. According to this classification, $L$. crinitus is in the highest temperature range in the group of mesophiles, close to thermophiles.

The temperature of mycelial biomass growth directly affects the energy expenditure and the production cost (COLAUTO et al., 2008). L. crinitus presents great growth from 31 to $34{ }^{\circ} \mathrm{C}$, but the growth at 28 or $37^{\circ} \mathrm{C}$ was still suitable. Thus, the adoption of optimal temperature for the mycelial biomass production will depend on the cost-benefit of the process and the possibility of energy reutilization in the process. In our study, this tendency of increase in the mycelial biomass up to $34{ }^{\circ} \mathrm{C}$ indicates increase in the physiological reactions of the microbial growth. Fungi of Lentinus genus grow in tropical environments at high temperatures. Moreover, according to Mswaka and Magan (1999), a temperature of $35^{\circ} \mathrm{C}$ was usually registered at midday inside tree logs. Thus, the in vitro growth results of our study are close to the ones found naturally in the growth environment of this fungus. 
The maximum mycelial biomass growth was when the cultivation medium $\mathrm{pH}$ was 6.1 . In general, an extreme $\mathrm{pH}$ (too basic or acid) denatures enzymes, making the mycelial biomass growth difficult. The optimal $\mathrm{pH}$ value obtained in our study for $L$. crinitus is close to the reported values of 5.5-6.0 for A. brasiliensis (COLAUTO et al., 2008), 4.5 for P. ostreatus (DIAZ et al. 2013), 6.5 for $V$. volvacea (SALES-CAMPOS et al., 2008), and 5-7 for L. strigosus (VARGAS-ISLA; ISHIKAWA, 2008).

The temperature and the $\mathrm{pH}$ of the cultivation medium mainly affect the speed of enzymatic reactions. Marim et al. (2018) evaluated the effect of temperature and initial $\mathrm{pH}$ in the liquid cultivation medium in the laccase activity of $L$. crinitus and reported a four-fold increase in the laccase activity when the optimal temperature was 28-30 ${ }^{\circ} \mathrm{C}$ and $\mathrm{pH}$ was 5.6-7.0. Therefore, the reported values of optimal temperature and $\mathrm{pH}$ for laccase production by $L$. crinitus are close to the ones obtained in our study of mycelial biomass growth. Marim et al. (2018) pointed out the differences of mycelial biomass growth and laccase activity for different strains of $L$. crinitus indicating the necessity of studies on bioproduct production for each strain.

In our study, an increasing addition of nitrogen in the cultivation medium inhibited the mycelial biomass growth of $L$. crinitus. The most significant inhibition occurred with non-protein nitrogen whereas the protein nitrogen was metabolically administered by fungus even in greater amounts. Niamke and Wang (2004) reported that the typical nitrogen sources are ammonium, nitrates and urea and in complex cultivation media are peptone, tryptone, yeast extract, wheat bran and digested protein. Chang and Miles (2004) cited that for basidiomycetes the nutrients must be readily accessible because most of the species have limited access to non-protein nitrogen such as nitrate and, therefore, the supply of a protein nitrogen source is essential. Bertéli et al. (2016) reported that the utilization of isolated soybean protein (protein nitrogen source) was more effective in the mycelial biomass growth of $A$. brasiliensis, without growth inhibition as occurred with sodium nitrate (nonprotein nitrogen source). According to Robbins (1939) reported that all fungus species utilize organic nitrogen (protein nitrogen) and a few ones use inorganic nitrogen (non-protein nitrogen). Moreover, Chang and Miles (2004) reported that some nitrogen sources are more appropriate to mycelial biomass growth of basidiomycetes than others, and that the necessary quantity for fructification is slightly greater than the quantity that supports the mycelial biomass growth. Very high nitrogen concentrations can inhibit fructification and/or mycelial biomass growth by the accumulation of toxic metabolic products or depletion of essential metabolites. In addition, Zhang et al. (2007) reported that high nitrogen concentrations inhibit enzyme synthesis in basidiomycetes. Thus, studies with variation of nitrogen sources and concentration are needed to determine the mycelial biomass growth of each fungus.

Nevertheless, in our study, L. crinitus was collected from a decaying tree trunk in nature. D'Agostini et al. (2011) reported that L. edodes grows better in substrates with reduced nitrogen concentration. These fungi are likely adapted to substrates with high carbon/nitrogen ratio such as decaying tree logs with carbon/nitrogen ratio of approximately 500 (REIS et al., 2012), where they are more competitive compared to other microorganisms, providing a natural selective advantage.

Non-protein nitrogen such as urea or ammonium sulfate can be converted into ammonia $\left(\mathrm{NH}_{3}\right)$ which is toxic for the mycelium, and results in reduced degradation of lignin in the cultivation of Pleurotus spp (RAJARATHNAM, BANO; STEINKRAUS, 2009). In our study, the nitrogen concentration (urea) inhibited inversely proportionally to the mycelial biomass growth of $L$. crinitus until complete inhibition. Silva et al. (2007) reported that the nitrogen concentration of $20.0 \mathrm{~g} / \mathrm{L}$ in the cultivation medium completely inhibited the mycelial biomass growth of Pleurotus sajor-caju, while in our study the concentration of $16.0 \mathrm{~g} / \mathrm{L}$ inhibited $95.1 \%$ of the mycelial biomass growth. Valle et al. (2014) reported that under optimal conditions for laccase activity with $L$. crinitus, the concentration of $2.8 \mathrm{~g} / \mathrm{L}$ of nitrogen (urea) inhibited in $72 \%$ of the mycelial biomass growth in liquid cultivation. According to D'Agostini et al. (2011), the addition of nitrogen in culture medium depends on the nitrogen source and species. They also reported that the mycelial biomass growth in the culture medium was hampered when nitrogen concentration was increased with ammonium sulfate for $P$. ostreatus and L. edodes, and urea for $A$. brasiliensis, both non-protein nitrogen sources. It suggests that each non-protein source need to be verified to each fungus before use, and that protein sources are far more acceptable for fungal growth. 


\section{CONCLUSIONS}

The best growth range of $L$. crinitus mycelial biomass is from 31 to $34{ }^{\circ} \mathrm{C}$ with optimal temperature peak at $32.7^{\circ} \mathrm{C}$, and the best initial $\mathrm{pH}$ of the cultivation medium is from 4.5 to 6.5 with optimal pH peak at 6.1. Protein or non-protein nitrogen concentration is inversely proportional to the mycelia biomass growth. Nitrogen concentrations of $2.0 \mathrm{~g} / \mathrm{L}$ of protein (soybean meal) and non-protein (urea) nitrogen inhibit the mycelial biomass growth in $11 \%$ and $12 \%$, respectively, but high concentrations of $16.0 \mathrm{~g} / \mathrm{L}$ of nitrogen inhibit $46 \%$ and $95 \%$, respectively. The protein nitrogen source causes lower inhibition than the non-protein source. Overall, the fungus is robust and grows under extreme conditions of temperature and $\mathrm{pH}$, but it has smaller adaptation capacity with increasing nitrogen concentrations in the cultivation medium, mainly with non-protein nitrogen.

\section{ACKNOWLEDGMENTS}

The authors thank Universidade Paranaense, Graduate Program in Biotechnology Applied to Agriculture, Fundação Araucária, Coordenação de Aperfeiçoamento de Pessoal de Nível Superior Brasil (CAPES) - finance code 001-, and Conselho Nacional de Desenvolvimento Científico e Tecnológico $(\mathrm{CNPq})$ for financial support and fellowship.

RESUMO: Lentinus crinitus é um basidiomiceto medicinal consumido por índios nativos da Amazônia brasileira. Este fungo tem sido estudado quanto ao potencial de biorremediação de metais, mas ainda carece de estudos sobre às condições básicas de crescimento. L. crinitus produz panepoxidona - um metabólito secundário fúngico - descrito como regulador da resposta inflamatória e imune em células animais. Este trabalho teve como objetivo avaliar as condições básicas de temperatura, $\mathrm{pH}$ e concentração e fonte de nitrogênio para o crescimento micelial de L c crinitus. O fungo foi crescido em meio agar extrato de malte a $2 \%$ (MEA), pH 5,5 e mantido entre 19 e $40{ }^{\circ} \mathrm{C}$. Para a avaliação de $\mathrm{pH}$ o MEA teve o pH ajustado de 2 a 11 e o crescimento foi realizado a $28{ }^{\circ} \mathrm{C}$. As fontes de nitrogênio estudadas foram a uréia e o farelo de soja adicionado ao MEA para obter entre 0,5 a $16 \mathrm{~g} / \mathrm{L}$ de nitrogênio, $\mathrm{pH}$ de 5,5 , cultivado a $28^{\circ} \mathrm{C}$. A melhor faixa temperatura para o crescimento micelial foi de 31 a $34{ }^{\circ} \mathrm{C}$ com ótimo a $32,7^{\circ} \mathrm{C}$; a melhor faixa de $\mathrm{pH}$ de 4,5 a 6,5 e com ótimo de 6,1. A concentração de nitrogênio proteico ou não proteico é inversamente proporcional ao crescimento do fungo. Concentrações de nitrogênio de $2,0 \mathrm{~g} / \mathrm{L}$ reduzem o crescimento da biomassa micelial em $11 \%$ e $12 \%$, respectivamente e meios com nitrogênio de $16,0 \mathrm{~g} / \mathrm{L}$ reduzem o crescimento em $46 \%$ e $95 \%$, respectivamente. $\mathrm{O}$ fungo é robusto e cresce sob condições extremas de temperatura e $\mathrm{pH}$, mas menor adaptação em meios com alta concentração de nitrogênio, principalmente não proteico.

PALAVRAS-CHAVE: Cultivo axênico. Crescimento micelial. Condição de cultivo. Farelo de soja. Lentinus crinitus. Uréia.

\section{REFERENCES}

AKINYELE, B. J.; ADETUYI, F. C. 2005. Effect of agrowastes, pH and temperature variation on the growth of Volvariella volvacea. African Journal of Biotechnology, v. 4, n. 12, pp. 1390-1395.

ALBUQUERQUE, M. P., NOGUEIRA, R. M.; NASCIMENTO, J. S. 2012. Mycelial growth of Lentinus sajorcaju (Fr.) Fr. and Pleurotus spp. in different agricultural wastes. Bioscience Journal, vol. 28, no 5, pp. 895-902.

ALMEIDA, P. H., et al. 2018. Decolorization of remazol brilliant blue R with laccase from Lentinus crinitus grown in agro-industrial by-products. Anais da Academia Brasileira de Ciências, v. 90, n. 4, pp. 3463-3473. https://doi.org/10.1590/0001-3765201820170458

BALLAMINUT, N.; MATHEUS, D. 2007. Characterization of fungal inoculum used in soil bioremediation. Brazilian Journal of Microbiology, v. 38, n. 2, pp. 248-252, https://doi.org/10.1590/S151783822007000200011 
BERTÉLI, M. B. D., et al. 2016. Agaricus subrufescens: substratum nitrogen concentration and mycelial extraction method on antitumor activity. Anais da Academia Brasileira de Ciências, v. 88, n. 4, pp. 22392246. https://doi.org/10.1590/0001-3765201620160161

CAMBRI, G., et al. 2016. Analysis of the biotechnological potential of a Lentinus crinitus isolate in the light of its secretome. Journal of Proteome Research, v. 15, n. 12, pp. 4557-4568.

https://doi.org/10.1021/acs.jproteome.6b00636

CHANG, S. T.; MILES, P. G. 2004. Mushrooms: cultivation, nutritional value, medicinal effect, and environmental impact. $2^{\mathrm{a}}$ ed., London: CRC. https://doi.org/10.1201/9780203492086

CHANG, S. T.; WASSER, S. P. 2012. The role of culinary-medicinal mushrooms on human welfare with a pyramid model for human health. International Journal of Medicinal Mushrooms, v. 14, n. 2, pp. 95-134, https://doi.org/10.1615/IntJMedMushr.v14.i2.10

COLAUTO, N. B., et al. 2008. Temperature and pH conditions for mycelial growth of Agaricus brasiliensis on axenic cultivation. Semina: Ciências Agrárias, v. 29, n. 2, pp. 307-312. https://doi.org/10.5433/16790359.2008v29n2p307

CONCEIÇÃO, T., et al. 2017. Study of the production of Lentinus crinitus (L.) Fr. lignolytic enzymes grown on agro-industrial waste. Advances in Bioscience and Biotechnology, v. 8, n. 8, pp. 259-272. https://doi.org/10.4236/abb.2017.88019

D'AGOSTINI, E. C., et al. 2011. Low carbon/nitrogen ratio increases laccase production from basidiomycetes in solid substrate cultivation. Scientia Agricola, vol. 68, nº. 3, pp. 295-300, ISSN 1678-992X. https://doi.org/10.1590/S0103-90162011000300004

DAS, A. R., et al. 2015. Growth of mycelial biomass and fruit body cultivation of Lentinus squarrosulus collected from home garden of Tripura in Northeast India. Journal of Applied Biology and Biotechnology, v. 3, n. 4, pp. 17-19,

DEACON, J. W. 2006. Fungal biology. $4^{\text {a }}$ ed. Oxford: Blackwell. ISBN-13 978-1-4051-3066-0.

DIAZ, R., et al. 2013. Influence of initial pH of the growing medium on the activity, production and genes expression profiles of laccase of Pleurotus ostreatus in submerged fermentations. Electronic Journal of Biotechnology, v. 16, n. 4, pp. 1-13. https://doi.org/10.2225/vol16-issue4-fulltext-6

EIRA, A. F. 2004. Fungos comestíveis. In: ESPÓSITO, E. and AZEVEDO, J. L. (Ed.) Fungos: uma introdução à biologia, bioquímica e biotecnologia. Caxias do Sul: Educs, pp. 379-448.

ERKEL, G., ANKE, T.; STERNER, O. 1996. Inhibition of NF-kB activation by panepoxydone. Biochemical and Biophysical Research Communications, v. 226, n. 1, pp. 214-221.

https://doi.org/10.1006/bbrc.1996.1335

ERKEL, G., WISSER, G.; ANKE, T. 2007. Influence of the fungal NF-кB inhibitor panepoxydone on inflammatory gene expression in MonoMac6 cells. International Immunopharmacology, v. 7, pp. 612-624. https://doi.org/10.1016/j.intimp.2007.01.001

FENG, Y. L., et al. 2010. Statistical optimization of media for mycelial growth and exopolysaccharide production by Lentinus edodes and a kinetic model study of two growth morphologies. Biochemical Engineering Journal, v. 49, n. 1, pp. 104-112. https://doi.org/10.1016/j.bej.2009.12.002

FIDALGO, O.; PRANCE, G. T. 1976. The ethnomycology of the Sanama Indians. Mycologia, v.. 68, n. 1, pp. 201-210. https://doi.org/10.1080/00275514.1976.12019902 
KIRK, P. M. 2019. Species fungorum (version Oct 2017). In: ROSKOV, Y., et al. (Ed.) Species 2000 \& ITIS Catalogue of Life, 2019 Annual Checklist. Accessed at: 2019-05-30. Available on:

http://www.catalogueoflife.org/annual-checklist/2019/

MANTOVANI, T. R. D., et al. 2012. Cryopreservation at -20 and $-70{ }^{\circ} \mathrm{C}$ of Pleurotus ostreatus on grains. Indian Journal of Microbiology, v. 52, n. 3, pp. 484-488. https://doi.org/10.1007/s12088-012-0289-4

MARIM, R. A., et al. 2018. Lentinus crinitus strains respond differently to cultivation $\mathrm{pH}$ and temperature. Genetics and Molecular Research, v. 17, $\mathrm{n}^{\circ}$ 1, 2017. https://doi.org/10.4238/gmr16039885

MARZLUF, G. A. 1997. Genetic regulation of nitrogen metabolism in the fungi. Microbiology and Molecular Biology Reviews, v. 61, n. 1, pp. 17-32. https://doi.org/10.1128/.61.1.17-32.1997

MILES, P. G.; CHANG, S. T. 1997. Mushroom biology: concise basics and current developments. Singapure: World Scientific. ISBN 9789810228774. https://doi.org/10.1142/3296

MSWAKA, A. Y.; MAGAN, N. 1999. Temperature and water potential relations of tropical Trametes and other wood-decay fungi from the indigenous forests of Zimbabwe. Mycological Research, v. 103, n. 10, pp. 1309-1317. https://doi.org/10.1017/S0953756298008491

NIAMKE, J. N.; WANG, N. S. 2004. Cellulose degradation by fungi. In: ARORA, D. K. (Ed.) Fungal biotechnology in agricultural, food, and environmental applications. New York: Marcel Dekker, pp. 595614. https://doi.org/10.1201/9780203913369.pt3

NIEBISCH, C. H., et al. 2010. Decolorization and biodegradation of reactive blue 220 textile dye by Lentinus crinitus extracellular extract. Journal of Hazardous Materials, v. 180, n. 1-3, pp. 316-322.

https://doi.org/10.1016/j.jhazmat.2010.04.033

PEÑALVA, M. A., et al. 2008. Ambient pH gene regulation in fungi: making connections. Trends in Microbiology, v. 16, n. 6, pp. 291-300. https://doi.org/10.1016/j.tim.2008.03.006

RAJARATHNAM, S., BANO, Z.; STEINKRAUS, K. H. 2009. Pleurotus mushrooms: Part III. Biotransformations of natural lignocellulosic wastes: commercial applications and implications. Critical Reviews in Food Science and Nutrition, v. 28, n. 1, pp. 31-113, https://doi.org/10.1080/10408398909527491

REIS, A. A., et al. 2012. Wood composition and charcoal of Eucalyptus urophylla in different planting locations. Pesquisa Florestal Brasileira, v. 32, n. 71, pp. 277-290. https://doi.org/10.4336/2012.pfb.32.71.277

ROBBINS, W. J. 1939. Growth substances in agar. American Journal of Botany, v. 26, n. 10, pp. 772-778, https://doi.org/10.1002/j.1537-2197.1939.tb09355.x

SALES-CAMPOS, C., et al. 2008. Mycelial growth of Pleurotus ostreatus in Simarouba amara sawdust. Pesquisa Agropecuária Brasileira, v. 43, n. 11, pp. 1633-1635. https://doi.org/10.1590/S0100204X2008001100024

SANCHEZ-LOPEZ, M. I., et al. 2008. Autochthonous white rot fungi from the tropical forest: potential of Cuban strains for dyes and textile industrial effluents decolourisation. African Journal of Biotechnology, v. 7, n. 12, pp. 1983-1990. https://doi.org/10.5897/AJB08.042

SANTANA, T. T., et al. 2018. Metallic-aromatic compounds synergistically induce Lentinus crinitus laccase production. Biocatalysis and Agricultural Biotechnology, v. 16, pp. 625-630.

https://doi.org/10.1016/j.bcab.2018.10.018 
SHARMA, V. P.; ANNEPU, S. K. 2018. Advancement in medicinal mushroom research. In: SINGH, B. and PETER, K. (Ed.). New age herbals. Singapore: Springer, pp. 151-162. https://doi.org/10.1007/978-981-108291-7_8

SILVA, G. T.; GIBERTONI, T. B. 2006. Aphyllophorales (Basidiomycota) in urban areas of the metropolitan area of Recife, PE, Brazil. Hoehnea, v. 33, n. 4, pp. 533-543, 2006.

SILVA, E. V., et al. 2007. Chemical analysis of fructification bodies of Pleurotus sajor-caju cultivated in several nitrogen concentrations. Ciência e Tecnologia de Alimentos, v. 27, n. 1, pp. 72-75.

https://doi.org/10.1590/S0101-20612007000100013

TANAKA, H. S., et al. 2019. Semisolid culture medium improves mycelial recovery of Agaricus subrufescens cryopreserved in cereal grains. Brazilian Journal of Microbiology, v. 50, n. 2, pp. 527-532, 2019.

https://doi.org/10.1007/s42770-019-00063-9

VALLE, J. S., et al. 2014. Optimum conditions for inducing laccase production in Lentinus crinitus. Genetics and Molecular Research, v. 13, n. 4, pp. 8544-8551, 2014. https://doi.org/10.4238/2014.October.20.31

VARGAS-ISLA, R.; ISHIKAWA, N. K. 2008. Optimal conditions of in vitro mycelial growth of Lentinus strigosus, an edible mushroom isolated in the Brazilian Amazon. Mycoscience, v. 49, n. 3, pp. 215-219, 2008. https://doi.org/10.1007/S10267-007-0404-2

WASSER, S. P. 2010. Medicinal mushroom science: history, current status, future trends, and unsolved problems. International Journal of Medicinal Mushrooms, v. 12, n. 1, pp. 1-16, 2010.

https://doi.org/10.1615/IntJMedMushr.v12.i1.10

WASSER, S. P. 2017. Medicinal mushrooms in human clinical studies. Part I. Anticancer, oncoimmunological, and immunomodulatory activities: a review. International Journal of Medicinal Mushrooms, v. 19, n. 4, pp. 279-317, 2017. https://doi.org/10.1615/IntJMedMushrooms.v19.14.10

WONG, K. H., HYNES, M. J.; DAVIS, M. A. 2008. Recent advances in nitrogen regulation: a comparison between Saccharomyces cerevisiae and filamentous fungi. Eukaryotic Cell, v. 7, n. 6, pp. 917-925, 2008. https://doi.org/10.1128/EC.00076-08

ZHANG, M., et al. 2007. Antitumor polysaccharides from mushrooms: a review on their isolation process, structural characteristics and antitumor activity. Trends in Food Science and Technology, v. 18, n.. 1, pp. 419, 2007. https://doi.org/10.1016/j.tifs.2006.07.013 